\title{
APPRECIATION AND CREATION IN CERAMIC ART LEARNING AS A FORM OF CULTURAL PRESERVATION FOR STUDENTS OF TK PANDEYAN 2 SUKOHARJO IN SURAKARTA RESIDENCY
}

\author{
Novita Wahyuningsih and Joko Lulut Amboro
}

Departement of Fine Art, Faculty of Art and Design, Sebelas Maret University, Surakarta.

\begin{abstract}
This study is aimed to describe the process of ceramic art learning process and to determine the impact of ceramic art learning for students of TK Pandeyan 2 Kindegarten of Sukoharjo by appreciating their creations. This method also intended to introduce and preserve ceramic culture for early age students. The method used is qualitative data analysis, in the form of data reduction, data presentation, and conclusion. The result shows that the ceramic art learning in TK Pandeyan 2 Kindegarten of Sukoharjo has positive effects as the teaching and learning process can be used as a medium for teachers and parents to understand children's characters and personalities better.
\end{abstract}

Keywords: art, ceramics, early childhood, appreciation, creation.

\begin{abstract}
Abstrak. Penelitian ini bertujuan untuk menggambarkan proses proses pembelajaran seni keramik dan untuk menentukan dampak pembelajaran seni keramik untuk siswa TK Pandeyan 2 Kindegarten dari Sukoharjo dengan menghargai kreasi mereka. Metode ini juga dimaksudkan untuk memperkenalkan dan melestarikan budaya keramik untuk siswa usia dini. Metode yang digunakan adalah analisis data kualitatif, dalam bentuk reduksi data, penyajian data, dan penyajian kesimpulan. Hasilnya menunjukkan bahwa pembelajaran dengan seni keramik di TK Pandeyan 2 Kindegarten dari Sukoharjo memiliki efek positif sebagai proses pengajaran dan pembelajaran. Untuk itu, teknik pengajaran ini dapat digunakan sebagai media untuk guru dan orang tua dalam memahami karakter anak-anak dan kepribadian dengan lebih baik.
\end{abstract}

Kata Kunci: seni, keramik, anak usia dini, apresiasi, kreasi

Early childhood or kindergarten age learning is a development phase for children from the day they were born to the age of six. Learning is done by giving educational stimulation to help their growth and development, physically and mentally, to prepare them entering further education. Children at early age have not entered any formal educational institutions yet, such as primary school education. In general, children at an early age only get education in the family and in the neighborhood or they follow the activities in various pre-school 
education institutions such as playgroups and kindergartens. Right now, early childhood learning is growing rapidly because early childhood education is used to prepare for successful development, the ability of children in the future, and to prepare for a higher level of education (Nurchasanah, 2013: 120).

Each child has their own specific thinking pattern. They have their own point of view regarding their environment. In order to motivate children's physical and psychological development, logic, and a sense of balance in public schools, learning art functions as a medium to play (recreational), a medium of expression, a medium of creativity, a medium of communication, and a medium of talent development (Shafi'i, 2005). Art creativity is often related with Quantum theory, which means art creating breakthrough in children's thinking. Accelerate their thinking capability and creativity (Sarjono, 2006: 208). Art education is important to give aesthetical experience to the students through appreaciating and creating art. It's important to give students experience to absorb and respond aesthetic phenomena in order to improve their creativity. Teaching art to children will also shape children to have sensitivity, aesthetical creativity, intuition, and critical sense to their environment (Sayuti, 2006). One of the efforts to develop the creativity of children is by learning ceramics (pottery) made of clay. As the medium to play, the activities of learning ceramic art are done joyfully, they do not burden children especially for kindergarten children. Therefore, the art lesson can neutralize fatigue and boredom when children have to learn a lesson that emphasizes logic. As a medium of expression, learning ceramic art is a means for children to express what they feel, what they think, and what they imagine. Accordingly, it will also sharpen children's creativity. There is no doubt that in order to foster creative and innovative power of children, one of which is through the study of ceramic art made of clay. Creative children will be able to produce new ideas, able to find solutions for various problems, and ultimately be independent. Something which is expressed by children through their artistic creativity will certainly be visible to others, teachers, or friends. Thus, communication through children's artistic work is created. For children who have special talents in art, art lesson becomes a means to develop their talent (Anwar McHenry, 2011: p. 2).

In TK Pandeyan 2 Sukoharjo, Surakarta residency, there are students at an early age who are very active, cheerful, and skilled. However, those children's creativity power must also be stimulated by being given early learning of ceramic art. The way to learn the art of ceramics is by playing through the medium of clay, so that the development of children at an early age in TK Pandeyan 2 Sukoharjo can be maximized. Children are allowed to mold the clay to their heart's content and always supervised by teachers. After the works created by the children are completed, the appreciation for the works can be given. The teachers of TK Pandeyan 2 Sukoharjo can give appreciation and evaluation with an interpersonal approach to the students to get successful results of the learning. The purposes of the study that will be achieved are to know how the learning process of ceramic art in kindergarten Pandeyan 2 Sukoharjo; determine the impact of the ceramic art of learning from the work of kindergarten students Pandeyan 2 Sukoharjo by the appreciation of the students' creations.

\section{METHOD}

The research entitled Appreciation and Creation in Ceramic Art Learning as a Form of Cultural Preservation for Students of TK Pandeyan 2 Kindegarten of Sukoharjo in Surakarta Residency takes place in TK Pandeyan 2 Kindegarten of Sukoharjo in Surakarta residency; and Melikan, a village in Klaten as a comparison. The development of ceramics or pottery in 
Melikan is quite a lot. Therefore, Melikan becomes the center of ceramic manufacture that can be used as a reference source. Besides, the myth about the origin of Melikan area that is closely related to the legend of Sunan Pandanarang can also be used as knowledge to support the cultural preservation in art education for children at an early age or kindergarten-aged children especially in TK Pandeyan 2 Kindegarten of Sukoharjo in Surakarta residency.

The data collected are qualitative data obtained from information given by resource persons, written resources, documentation and archives, works of pottery, as well as the activities of pottery making by the kindergarten students. The resource persons of this study include the Head of Melikan village; potters in Melikan, potters using tilted potter's wheels, some researchers, cultural observers, ceramic observers in Tembayat, educators, and teachers of TK Pandeyan 2 Kindegarten of Sukoharjo.

The data obtained in the field and from related parties are then collected and analyzed by a qualitative method. The results of observation in the field and at the ceramic manufacture in the form of photos and recorded activities of making ceramics by students of TK Pandeyan 2 Kindegarten of Sukoharjo, the results of the interviews with the resources about the life of ceramics or pottery in Melikan, and the literary data about Melikan ceramics and Javanese culture, then are collected and collated through the process of typing and editing.

The process of data analysis in this research is conducted qualitatively by three ways. Data reduction is a process of selecting, focusing, and simplifying all data collected in the field. Data presentation is a series of description in the form of a complete narration. It describes what happens in the field of research. The presentation of data is done objectively and authentically. The presentation of data subsequently is used to draw conclusions and to obtain findings.

\section{FINDINGS AND DISCUSSION}

\section{Appreciation and Creation in Ceramic Art}

The appreciation of art is needed to sustain the existence of art itself. Therefore, various groupings by some experts in education about the process of art appreciation come into existence. Feldman (1967) and Smith (1967) in Bella (2011: 23) classify the activities of art appreciation based on the perception and intellectual process through four stages, namely:

\section{a. Describing}

Viewing the results of art and describing the characteristics that are seen such as colors, lines, shapes, appearance, combination, and elements of composition that are principles and structures.

\section{b. Analyzing}

Analyzing the relationship of seen traits such as the elements of art, principles and structures, analyzing the expressive qualities such as mood and atmosphere, explaining the style of work. 


\section{c. Interpreting}

Looking for meanings contained in the characteristics that are seen such as the subject, symbols, elements of art, principles, structures, styles and materials; looking for metaphors (simile / figurative) and analogies (equations) to explain the meaning.

\section{d. Appraising}

Making judgments based on criteria that are suitable such as originality, composition, techniques and functions; assessing the work of art based on its meaning in terms of individual, social, religious and reliant, historical and artistic aspects.

There are several approaches to art appreciation, for examples applicative, introduction to the history and problematic approaches. Appreciation through an applicative approach is cultivated by conducting direct work of art in a studio, at school, at home, or anywhere. Practices of doing art are embodied and connect body and mind (Johnson, 1987, p. xiv-xvi; Borgdorff, 2007; Brinck, 2007, p. 407 in Hautala, 2015:p. 2). Through practical work, appreciation grows necessarily as a result of consideration and comprehension of the process of the work in terms of uniqueness of the techniques, materials, and etc. Through the work of art, various considerations of the techniques used by the creators in the process of making the work of art can be perceived (Ponimin, 2009). Working with the medium of ceramic or clay will certainly provide a different sensation from using the medium of stone or wood, although both types of media can be used to create works of art. The more knowledge about the techniques, tools, and materials used in the work of art is, the more insight people have to appreciate the work of art. The applicative approach can also be done by looking at the process of the work done by the creators directly.

The appreciation with an approach of the introduction to the history can be nurtured through the introduction to the historical development of art and culture. In everyday practice in a simple way, the origin of a piece of art can be examined, for example the history of ceramic or pottery making in Melikan. The questions are about the function of the work of art, when it was made, then it is compared with the current function, who made it, where the ceramic or pottery was produced, and when the making was done. Appreciation with this kind of approach is not enough to be done by visiting a museum or seeing the various works of art inherited by creators in the past. The appreciation with the approach of introduction to history requires a willingness to learn more about the works of art that are seen.

In addition to applicative and historical approaches, there is also appreciation through a problematic approach, which starts with recognizing the physical and non-physical elements (elements and principles of art) found in a work of art. The next step is to figure out the size of the work, and recognize the techniques and materials used, the theme and the selected object.

The characteristic of typical art teaching materials as an activity is a creative process, which in its implementation is realized as expressive, constructive, and appreciative activities. Each activity contains the potential for the development of basic capabilities of the students, especially kindergarten-aged children, mainly the development of aspects of feelings and aesthetic impulse. There are two creative processes, namely artistic creativity (creation process) and aesthetic creativity (process of full comprehension). Creativity can occur in several areas including: a) activities to express ideas, activities to think, activities to daydream and fantasize; b) activities to express artistically or visually; c) activities to do 
physical work that will implement and validate the ideas that have been composed (Putra, 2014: 3).

\section{Motoric Development of Kindergarten-Aged Children}

According to Kartini Kartono in Syaodih (2005: 13) the characteristics of childhood are marked by several things, namely: 1) egocentric naïve characteristic. Children who are naively egocentric view the world outside using their own point of view, according to their knowledge and understanding, which is still limited by a narrow mind. Children do not understand the true meaning of an event and have not been able to put themselves in the lives and minds of others. It is also called egocentric; 2) primitive social relation. Primitive social relation is the result of egocentric naïve characteristic. It is characterized by children's life that can not differentiate their situations from the circumstances of their social environment, which means that the children can not distinguish between their own conditions and the conditions of other children; 3) physical and spiritual unity which is almost inseparable. Children in early childhood have not been able to distinguish between physical and spiritual world. Children's full understanding of something is expressed freely, spontaneously, and honestly, in the forms of expression, behavior, and language. Children can not lie and pretend to behave; 4) physiognomic life attitude. Children are physiognomic towards their world. It means that directly children give the physical or concrete characteristics of reality based on what they understand fully. This is because children's understanding of what they face still unites (total) the physical and spiritual characteristics. Children are not able to distinguish between living and nonliving objects. Everything around them is considered to have a soul, and is considered living beings that have the body and soul at the same time.

Explains that motoric development is defined as the development of mature control of body movements and brain as a center of motion. That development requires an active effort from children and support from the environment. It is expected that the active actions of the environment can develop the fine motoric skills of children. Motoric development is done with practice individually. Motoric development in children of kindergarten or children in early childhood really need more frequency and opportunities so that children can develop their physical activities fundamentally, such as running, jumping, throwing, pushing, pulling, and so on. These activities also train the concentration to move in coordination with other senses (Rasyid, 2009: 111).

\section{The Process of Forming Ceramics Made of Clay in TK Pandeyan 2 Kindegarten of Sukoharjo}

Sumantri (2005: 156) adds that the steps to form the ceramics made of clay are as follows: 1) Ough of clay that is safe for children is selected; 2) Children are arranged so that they are not crammed when they do the activity of making ceramics; 3) Teachers need to equally give attention by walking around, observing, communicating, helping children who have difficulty; 4) Teachers can encourage children to engage in dialogue about the work created; 5) Teachers can provide reinforcement such as by giving compliment, saying children's names, patting children's shoulders and smiling at them so that they are eager to do their job. The steps of making ceramics by students of TK Pandeyan 2 Kindegarten of Sukoharjo, Surakarta residency in a relaxed and cheerful manner are seen in the picture 1. 


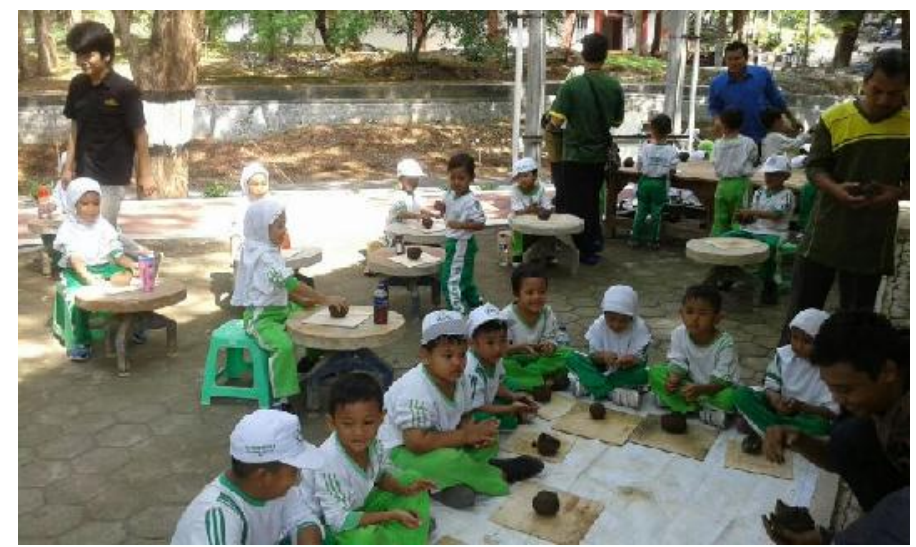

Figure 1. The atmosphere of the process of ceramic art learning by students of TK Pandeyan 2 Kindegarten of Sukoharjo in Surakarta residency.

Source: Documentation of the field, 2016.

The process of ceramic formation requires manual skills that are started from kneading clay to become homogeneous to finishing. The forming of ceramics can be done by hand directly (handbuilt) or with the help of other tools such as a rotary tool, jigger-jolley, printing equipment, and so on. According to the Ponimin dalam Tri Atmojo (ed.). 2015: 119), the process of forming the ceramics can be divided into several techniques, namely: 1) pinching; 2) coiling; 3) slab building; 4) throwing; and 5) moulding.

The forming of ceramics by hand (handbuilding) is one of the techniques in the making of ceramics in which an object (clay) is directly molded by hands. This technique is also applied to the ceramic art learning for students of TK Pandeyan 2 Kindegarten of Sukoharjo. This process consists of techniques of making ceramics using hands in various ways such as pinching, coiling, slab building, and free style techniques. This is a technique for beginners in making ceramics, for examples simple objects, such as bowls, or irregularly organic shapes. The results of pinching will appear from the pressure of thumbs and index fingers. The functions of pinching with fingers are to direct the form of the ceramic objects that will be created, as well as to flatten the overall thickness of the ceramics (Ponimin, 2005: 72-73). Ceramics made by using this pinching technique are ceramics that are relatively small to moderate. This technique is particularly attractive because children can make ceramics spontaneously and are intimate with the clay. The making of ceramics with this technique is largely done by hand without the help of other tools, tools are rarely used (Ponimin dalam dalam Tri Atmojo, ed., 2015: p. 105). Through ceramic art learning given, teachers can also know the potential that belong to the students of TK Pandeyan 2 Kindegarten of Sukoharjo by giving appreciation for the works of ceramics that have been made in accordance with the theory. They are describing, analyzing, interpreting, and evaluating. For an example, if children create ceramics less neatly, it is possible that the children have a feeling or mood that is resless, hurried, and lack of concentration. Art education is intended to interpret the art in order to shape the whole person. The teachers's role is to mentor and give an example that to make ceramics, students should be relaxed, calm, not be afraid to be left by their friends who have already completed the work. Moreover, it should be stressed that the final form of the ceramic is not a result that will be assessed. The more important is the formation process and the response received by children when they learn ceramic art. Thus, the children will not be burdened with the final shape that should be perfect, will not worry if their work 
will be compared to the work of other children. However, they have the freedom and flexibility to work to develop their creativity without hesitation.

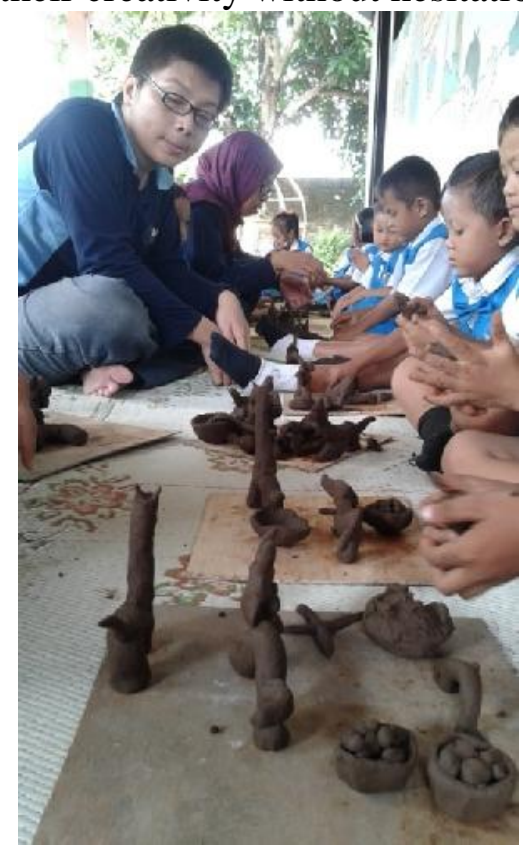

Figure 2. Assistance given by teachers to students of TK Pandeyan 2 Kindegarten of Sukoharjo in Surakarta residency in the process of ceramic art learning.

Source: Documentation of the field, 2016.

The role of teachers in the process of ceramic art learning by students of TK Pandeyan 2 Kindegarten of Sukoharjo is determining the nature, characters, feelings, and other things from the inside of each child through the appreciation given. For example, when children create ceramics with clay into shapes of animals, but they do not make ornaments of eyes, teachers can know that the children who make the ceramics have a careless habit. Therefore, the teachers' role is to provide corrections, examples, and assistance to the children to work more carefully. It will be different if the teachers find ceramics that are made carelessly because the children are feeling angry, upset for any reason. Then the role of the mentors must also be able to make the children get rid of their anger or bad mood so that they can be cheerful and better ceramic works will also be formed. Through the process of appreciation of the ceramic works made by students of TK Pandeyan 2 Kindegarten of Sukoharjo, educators, teachers, and parents can interpret and assess the prosess of child development that becomes their responsibilty. Therefore, things that are not good in the process of child development can be identified and fixed.

\section{Ceramic Art as a Means of Cultural Preservation for Students of TK Pandeyan 2 Kindegarten of Sukoharjo in Surakarta Residency}

Indonesian culture has various characters which can be differed as visual and symbolical character. Some of them potential to be developed to keep it alive and use as needed in their era According to Sumanto (2005: 191) the purposes to use the natural and cultural environment in the art learning in kindergartens are: 1) the learning can be more effective, with an environment that is already known to children, the children can accept and master the learning well; 2) lessons can be relevant to students' needs in accordance with their 
interests and development; and 3) it will be more efficient, cheap, and affordable, for example by using natural materials like clay.

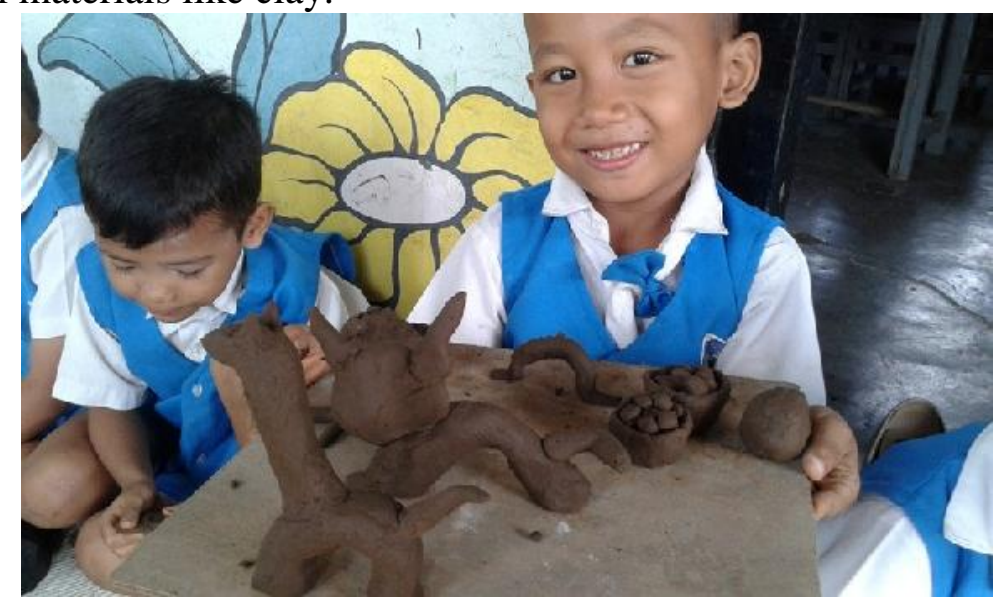

Figure 3. The artworks of ceramics successfully made by students of TK Pandeyan 2 Sukoharjo in Surakarta residency.

Source: Documentation of the field, 2016.

In the process of learning of ceramic art made of clay in TK Pandeyan 2 Kindegarten of Sukoharjo, teachers can also insert information related to art appreciation through applicative, historical, and problematic approaches. Art could develop culture comprehension with chance to create internalization of related culture. An applicative approach occurs when teachers teach ceramic art in the classroom or in the natural environment, so that students get the opportunity to develop their potential to the fullest. Besides in Indonesia, teaching local arts, abundant and full of cultural diversity also occur in every corner of Turkey, as elective courses will not only provide students with opportunities for hobbies and potential future careers but also be a means of passing these arts on to the future generations. Some of the famous local arts and cultural heritages of Turkey that could be presented as elective courses are pottery in Nevsehir and Canakkale; tile making in Kutahya and Iznik; filigree in Mardin; meerschaum in Eskisehir; sericulture in Bursa; clarinet in Trakya (Thrace); oilwrestling in Edirne; zeibek folk dance in Ege (Aegean Region); jet stone decorations in Erzurum; carpet and rug making in Usak and Balikesir; wood, stone and cupper decorations and kemancha training in Trabzon; knife making in Kastamonu and Denizli Yatagan, etc (Bayindir, (at al.). 2015: p. 2868).

In the process of applicative approach, a historical approach can also be done, for example by recounting the history of the emergence of the process of making ceramics in Melikan, Klaten, which began with the coming of Sunan Pandanarang to the area in the past. After living in Melikan, the wife of Sunan Pandanarang was sent to make a padasan (a vat made of clay). Because at that time a Javanese woman always dressed in kebaya and jarik, the wife of Sunan Pandanarang had difficulty to make the padasan by using an ordinary potter's wheel. Therefore, Sunan Pandanarang then created a tilted potter's wheel as a tool for making pottery. With this tool then various types and shapes of ceramics from clay, such as anglo (braziers), kuali (pots for cooking), cobek (mortars) were created. The ceramics can also be shown to students as the examples of ceramic forms of the past so that they can be replicated. Children can also be given an explanation that in the past, the proces of making ceramics was not much different from the current period, and most of the process was done by hand. If students have difficulty then the problematic approach can be done by providing 
assistance and support, such as by giving examples of how to make ceramic parts, how to refine, and so on.

\section{CONCLUSIONS AND SUGGESTIONS}

One of the efforts to support the development of kindergarten-aged children in TK Pandeyan 2 Kindegarten of Sukoharjo in Surakarta residency is by learning ceramic art made of clay. Ceramic art learning can be used as a way to appreciate and develop the creativity of students of TK Pandeyan 2 Kindegarten of Sukoharjo in Surakarta residency in order to know their potential, intelligence, personal development, feelings, or even deficiencies that later can be handled by teachers and parents so that the growth of body and soul of kindergartenaged children can be maximized. By teaching ceramic art, indirectly teachers also convey a moral message about the importance of preservation of ceramic culture so that it won't disappear because of the development of the more modern era.

\section{REFERENCES}

Anwar McHenry, Julia. 2011. Rural Empowerment through the arts: The role of the arts in civic and social participation in the Mid West region of Western Australia. Journal of Rural Studies, 27 (2011) 245e253, p. 2

Bayindir, Nida, (at al). 2015. The need for teaching local arts as an elective course: the art of tile making in Kutahya, Procedia Social and Behaviour Sciences. 174 (2015) 2867 - 2874

Bella, Maria Orchita. 2011. Graha Apresiasi Seni Lukis di Yogyakarta. Yogyakarta: Program Studi Arsitektur, Fakultas Teknik, Universitas Atma Jaya.

Hautala, Johanna. 2015. Interaction in the artistic knowledge creation process: The case of artists in Finnish Lapland. e-journal Geoforum, p. 2. http://dx.doi.org/10.1016/j.geoforum.2015.01.002.

Nurchasanah, 2013. Pengembangan Bahan Ajar Untuk Meningkatkan Perilaku Anak Prasekolah Melalui Kreativitas Bahasa. Jurnal Bahasa \& Seni: Bahasa, sastra, Seni, dan Pengajarannya, Tahun 41 Nomor 1 Februari 2013: p. 120

Ponimin, 2005. Desain Keramik Kasongan dalam Konteks Perubahan Sosio Kultural. Jurnal Bahasa \& Seni: Bahasa, sastra, Seni, dan Pengajarannya, Tahun 33 Nomor 1 Februari 2005, p. 72-73

Ponimin, 2009. Pengembangan Desain Produk Keramik Elemen Estetik Bernuansa Kearifan Budaya Lokal Melalui Revitalisasi Ragam Unsur Budaya Lokal Jawa Timur untuk Meningkatkan Nilai Seni Kriya Keramik. Jurnal Studi Sosial. Vol.2, 72-73

Ponimin, 2015. Keramik Dinoyo Malang: dari Gerabah lokal Hingga Keramik Seni, dalam Tri Atmojo, Wahyu (ed.).. Keramik Tiga Karakter: Medan, Yogyakarta, Malang, Medan: Perdana, p. 104

Putra, I Nyoman Juanda, et. al. 2014. Pengaruh Aktivitas Pembelajaran Apresiasi Seni terhadap Pemahaman Siswa Mengenai Seni Karawitan Ditinjau dari Kemampuan Artistik Siswa di SMA Negeri 1 Semarapura. e-Journal Program Pascasarjana Universitas Pendidikan Ganesha Program Studi Penelitian dan Evaluasi Pendidikan (Volume 4 Tahun 2014, p. 3

Rasyid, Harun. (et. al). 2009. Asesmen Perkembangan Anak Usia Dini. Yogyakarta: Multi Pressindo. 
Sarjono, 2006. Berbagai Pola Pikir dalam Proses Kreativitas Berkarya Seni. Bahasa \& Seni - Jurnal Bahasa, Sastra, Seni, dan Pengajarannya. Vol. 2, p. 208

Shafi'i, dkk, 2005, Materi dan Pembelajaran Kertakes SD. Depdiknas: Universitas Terbuka.

Sumanto. 2005. Pengembangan Kreatifitas Seni Rupa Anak TK. Jakarta: Departemen Pendidikan Nasional.

Sumantri. MS. 2005. Model Pengembangan Keterampilan Motorik Anak Usia Dini. Jakarta: Depdiknas.

Syaodih, Ernawulan. 2005. Bimbingan di Taman Kanak-kanak. Jakarta: Departemen Pendidikan Nasional Departemen Jenderal Pendidikan Tinggi. 